\title{
1920-1945 Akımlar Dönemi Kapsamında İç Mimarlıkta Form
}

\author{
İsmail Emre KAVUT 1*(D), Nedim ALICi 2 (D) \\ ORCID 1: 0000-0003-2672-4122 \\ ORCID 2: 0000-0002-2648-5822 \\ ${ }^{1}$ Mimar Sinan Güzel Sanatlar Üniversitesi, Mimarlık Fakültesi, İç Mimarlık Bölümü, 34427, İstanbul, Türkiye. \\ ${ }^{2}$ Sinop Üniversitesi, Tasarım Bölümü, 57400, Sinop, Türkiye. \\ *e-mail: nedim_alici@hotmail.com \\ Öz \\ Metinde, genel anlamda 20. yy'ın ilk yarısı ele alınarak, bu süreçte akımlar etkisiyle iç mimarlıkta yaşanan \\ değişimler form kavramı çerçevesinde incelenmektedir. Bu kapsamda iç mimarlıkta yaşanan biçimsel \\ değişimlerin sebep sonuç ilişkisi ile birlikte aktarılması amaçlanmaktadır. Tarihsel süreçte çeşitli olaylar, \\ gelişmeler, yenilikler ve bunlardan doğan etkiler ile akımlar ortaya çıkmaktadır. Siyasi gelişmeler ve ekonomik \\ şartlar güç dengelerini değiş̧tirmiş, toplumsal yapıda sınıfsal farklııklar oluşmuş buna bağlı olarak mimari ve iş \\ mimari anlamda yeni istekler, ihtiyaçlar, beğeni ve beklentiler oluşmuştur. Bu durum akımları besleyerek \\ değişim ve dönüşüme katkı sağlamışır. Mekân ve insan ilişkisi göz önüne alındığında, mekanların tarihsel süreç \\ içinde oluşan toplumsal ürünler oldukları gözlemlenir. Bu bağlamda toplumun içinden geçtiği süreçleri yapılar \\ üzerinde gözlemlemek mümkün olmaktadır. Tarihi süreç içerisinde ortaya çıkan akımların etkileri mimari \\ yapılarda da görülebilmektedir. Mimari akımların farkılıklarla birlikte benzerlikleri de bulunmaktadır. Bu \\ sebeple mimari eserler incelenirken tek bir akım içinde kalmayıp farklı akımların etkilerinin de olduğu \\ gözlemlenmektedir.
}

Anahtar Kelimeler: Iç mimarlık, mekân, tasarım, akımlar, form

\section{Form in Interior Architecture in the 1920-1945 Period}

\begin{abstract}
In the text, the first half of the 20th century is discussed in general, and the changes in interior architecture with the effect of currents in this process are examined within the framework of the concept of form. In this context, it is aimed to convey the formal changes in interior architecture together with the cause and effect relationship. In the historical process, various events, developments, innovations and the effects arising from them and movements emerge. Political developments and economic conditions have changed the balance of power, class differences have occurred in the social structure, and accordingly, new demands, needs, tastes and expectations have emerged in terms of architecture and interior architecture. This situation has contributed to change and transformation by feeding the currents. Considering the space and human relationship, it is observed that spaces are social products formed in the historical process. In this context, it is possible to observe the processes that the society goes through on the structures. The effects of the currents that emerged in the historical process can also be seen in architectural structures. Architectural movements have similarities as well as differences. For this reason, when examining architectural works, it is observed that there are effects of different movements, not staying in a single movement.
\end{abstract}

Keywords: Interior architecture, space, design, movements, form

Citation/Atıf: Kavut, i.E. and Alici, N. (2021). 1920-1945 akımlar dönemi kapsamında iç mimarlıkta form. Journal of Architectural Sciences and Applications, 6 (2), 621-637.

DOI: https://doi.org/10.30785/mbud.970538 


\section{Giriş}

iç mimarlık; mimari yapı içinde bulunan hacimlerin, kullanıcı ihtiyaçlarını karşılayacak şekilde örgütlenmesi, mekân konforuna katkı sunması, renk, aydınlatma, form, malzeme, doku, donatı elemanları ve aksesuar öğelerinin iç mimar tarafından düzenlenerek tasarlanmasını kapsamaktadır. i̇ç mimarlığın tarihsel akışı göz önüne alındığında, II. Dünya Savaşı sonrası yeni yapılanma döneminde, konut ihtiyaçlarının karşılanması amacıyla kurulan büyük şirketlerin öncülüğünde, iç mimari tasarım gerçeklik kazanmaya başlamıştır. Frank Lloyd Wright, Alvar Aalto, Le Corbusier gibi tasarımcıların iş mekân tasarımına önem vermeleri iç mimarlığın ayrı bir disiplin olarak gelişmesinin temellerini atmıştır.

20. yüzyılda sosyal ve siyasi yapı, ekonomik koşullar, din olgusu, bilimsel ve sanatsal gelişmeler mimarlığın hızla değişmesine ve yeni mimari anlayışların ortaya çıkmasına sebep olmuştur. Sanatsal ve bilimsel gelişmelerin hızla yaşandığı bu yüzyılda çok sayıda akım ortaya çıkmıştır. Bu akımlar mimari ve iç mimari alanda; malzeme, doku, renk, süsleme, biçim, işlev ve form gibi çeşitli özellikleri ile birbirinden ayrılmaktadır.

İç ve dış mekânı ayıran yapı kabuğu, mimari ile iç mimarinin birleşim noktası gibi gözükse de gerçekte bu iki disiplini birbirinden ayıran bir öğe olarak da tanımlanmaktadır. İç mekân tasarımcıları zaman zaman bu mimari öğeyi tasarımlarına dahil ederek kullanmaktadır. İç mekânda üçüncü boyutun tasarıma dahil olması iç mekânın bir form olarak tasarlanabileceğini göstermektedir.

Bu çalışmada; iç mekânda üç boyutluluğu oluşturan form kavramı, mekânın form olarak ele alınması, örgütlenme ilkeleri aracılı̆ıyla tasarlanması ve 1920-1945 dönemi akımlar kapsamında incelenmesini kapsamaktadır. Bu kapsamda iç mimarlıkta yaşanan biçimsel değişimlerin sebep sonuç ilişkisi ile birlikte göz önüne alınarak araştırılması ve iç mimarlık alanına bu konuda katkı sunması amaçlanmaktadır.

\subsection{Materyal ve Yöntem}

Toplumların güncel durumu ve geçmiş dönemlerindeki sosyal, siyasal, sanatsal, bilimsel ve dini yapılarından etkilenerek ortaya çıkan akımlar, sanat ve bilim gibi alanlar başta olmak üzere çeşitli alanlarda kendini gösteren gelişmeler ve yeniliklerdir. Akımlar ile yaşanan gelişmelerin birçok alanda etki göstermesi ile beraber, mimarlık alanında da büyük yenilikler ve gelişmeler görülmüştür. Ortaya çıkan bu akımlar toplumun sosyo-kültürel dinamiklerinden bağımsız olarak düşünülemeyeceğinden, ilk olarak bu dinamikleri incelemek gerekmektedir. Bu bağlamda 1920-1945 tarih aralığı sosyokültürel dinamikleri olan; siyaset, ekonomi, din, bilim, sanat başılklarını incelemek gerekmektedir. Bu dinamikler etkisi ile ortaya çıkan; Konstrüktivizm, Bauhaus, De Stijl, Pürizm ve Modernizm akımları araştırma kapsamı olarak belirlenmiştir.

Bu çalışmanın temel amacı, tarihi süreçte sanat ve mimaride ortaya çıkan akımların mimari ve iş mimari alanlarında yaptıkları etkileri form kapsamında ele alarak incelemek ve dönemsel farklılıkların birbirleriyle olan benzer/farklı ilişkilerini ortaya koymaktır. Araştırma, yazılı ve görsel veri kaynaklarından faydalanılarak, nitel araştırma yöntemlerinden doküman inceleme yöntemi kullanılarak hazırlanmıştır. Makale, 1. Dünya Savaşı sonrası ve 2. Dünya Savaşı sonuna denk gelen tarih aralığını kapsayan kesitsel bir çalışmadır. Bu süreçte; etkisi devam etmekte olan, yeni ortaya çıkan ve bu sürecin etkisi ile sonradan ortaya çıkmış olan akımlar ele alınmıştır.

\subsection{0-1945 Dönemi Sosyo-Kültürel Dinamikler ve Mimariye Etkileri}

19. yüzyıl sonlarında değişim kuvvetleri; batı toplumunu, monarşiden demokrasiye, dinsel sofuluktan din dışı kaygılara, sanatta aristokratik beğeniden endüstriyel girişimcilerin ve orta sınıfın beğeni anlayışına doğru olağanüstü bir biçimde değiştirdi (Roth, 2000). Bu büyük değişimler gelecek yüzyıl mimari anlayışları üzerindeki en belirgin ve baskın değişimler olmuştur. 19. yüzyılda çoğunlukla bölgesel olarak gelişen yapılanma süreci, bu yüzyılın sonuna doğru saflaşarak üsluplara dönüşmüş ve bu şekilde 20. yüzyıla doğru adım atılmıştır.

20. yüzyıl farklı akımların bir arada olduğu bir dönem olarak öne çıkmakla birlikte, bu süreçte ortak değerlere ulaşma kaygısından ziyade öznel kural ve değerler ön plana çıkmıştır. Mimarlıkta önceki 
anlayışların aksine sayısal değerler tartışma konusu olmuş, işlev ve anlam ön plana çıkmış, form ise bunlardan sonra gelmiştir. Bu bağlamda akımlara bakıldığında farklıııklar olduğu kadar benzerlikler de göze çarpmaktadır.

Akımların mimarlık alanına yapmış olduğu etkiler ele alındığında, sosyal yapının göz önüne alınması ve incelenmesi gerekmektedir. 19. yüzyıl toplumlarında, insanların dış görünüşleri kişilerin sosyal mevkiinin anlaşılmasına sebep olmaktaydı. 20. yüzyılda imkanların artması ve endüstriyel gelişmeler; insanların sokaklarda tek tipleşmesine, üzerlerinde taşıdıkları kıyafetler ile yalıtılmış şekilde kalabalığa karışabilmesine olanak sağlamıştır. Bu yüzyıldan itibaren gelişmelerin hız kazanması, ekonomik refahın ve ulaşılabilirliğin toplumun her kademesi için artmasından dolayı, insanlar görsel olarak sıradanlaşmış kendi görsel özgünlüğünü yitirip makinelerin ifadesi haline gelmişlerdir.

Sosyal yapının yansımaları mimari alanda da görülmektedir. 20. yüzyı öncesi toplum düzeni; üst sınıf olarak din adamları, aristokratlar, toprak sahipleri ve alt sınıf olarak iş̧̧ilerden oluşmaktaydı. Yaşanan gelişmeler vasıtasıyla sınıfsal farklılıkların silikleşmesi, sanayileşmenin ve endüstriyel sistemlerin gelişmesi ile insanlar kırsal bölgelerden ayrılarak şehirlere göç etmeye başlamıştır. Bu yolla aile kavramının küçülmesi ve çekirdek aile kavramının ortaya çıkmasından dolayı, şehirlerde küçük konutlar üretilmeye başlanmıştır. Bu konutların seri üretim yöntemi ile inşa edilmeleri yaşam çevrelerinin aynılaşmasına neden olmuştur. Benzer biçimde bu mekânlarda kullanılan mobilyalar, renkler ve formlar da seri üretimden etkilenerek zaman içinde tek tipleşmeye başlamıştır.

Toplumun sahip olduğu; siyaset, ekonomik, din, bilim ve sanat gibi değişim ve dönüşüm dinamizmleri etkisi ile akımlar ortaya çıkmış, gelişmiş ve yeni akımların oluşmasına da zemin hazırlamıştır.

\subsubsection{Siyaset}

19. yüzyıl sonları ve 20. yüzyıl başlarında; Avrupa'da ortaya çıkan siyasi ve ekonomik hareketlilikle beraber, yönetimlerin monarşiden demokrasiye dönüşümü, devletlerin çekişme ve güç gösterileri ile ortaya çıkan toprak paylaşım savaşlarından kaynaklı, mimarlık belli dönemlerde kesintiye uğramıştır. Ortaya çıkan savaşlardan dolayı, gelişmekte olan sanayileşme ve endüstriye dayalı üretimler durma seviyelerine gerilemiş, mimari anlamda üretimler de bu tür sebeplerden kaynaklı olumsuz etkilenmiştir. Bu dönemlerde bazı mimarlar zorunlu olarak bulundukları ülkeleri terk etmek durumunda kalmıştır. Siyası yapıların; toplumda alt ve üst sınıf farklılıklarını eski dönemlere kıyasla azaltmış olmasından dolayı, insanların mimari beklentileri benzer duruma gelmiştir. Bu tür siyasi etki sonucunda ortaya çıkmış olan etmenler sadece toplum düzeni değil, dönemin mimari anlayışlarına da etki etmiştir.

Savaşlar kentlerin değişim ve gelişiminde çok büyük rol oynamıştır. Kentlerin yıkımı ve yaşanan felaketler dışında, savaş mimarisi ile de çok sayıda yapı ortaya çıkmış ve şehir bünyesinde yerini almıştır. Savaş için silah yapımında kullanılan çelik ve daha birçok malzemenin üretilmesi için büyük fabrikalara intiyaç duyulmuştur. Karargahlar, esir kampları, askeri yerleşmeler gibi yapıların tasarlanması gerekmekteydi. Savaş, böylece bir organizasyon faktörü haline gelmiştir. Savaşlar ile kentlerin büyük bir kısmı yok olmuştur ve yeni anıtsal yapılar yapılmıştır. Savaş, çok sayıda kentsel ölçekte büyük yapının inşa edilmesine sebep olmuştur (Öztürk, 2010). Amerikalı mimar George Bergstrom tarafından tasarlanan, ABD'nin Savunma Bakanlığı ve Genelkurmay Başkanlığı olan Pentagon binası 1942-43 yılında inşa edilen önemli yapı örneklerinden sayılır.

\subsubsection{Ekonomi}

Bu yüzyılda oluşan şartlar ile birlikte ekonomik güç dengeleri değişime uğramıştır. Ordu, kilise ve aristokrat sınıfının elinde bulunan güç, endüstri ve sanayideki gelişmeler ile üretici ve işveren konumundaki burjuva sınıfının eline geçmiştir. Bu bağlamda sanayicinin ön plana çıkması, dünya tarihinde feodalite ve aristokrasi devrinin kapanıp, sermayecilik ve kapitalizm döneminin başlaması olarak kabul edilmiştir. Toplumsal yapıda ortaya çıkan bu sınıfsal yenilikler, yeni bir işveren ve onların istekleri, ihtiyaçları için yapılan yeni mimari anlayışları da beraberinde getirmiştir.

Endüstri ve beraberinde teknolojik gelişmelerin hız kazanması, 19. yüzyıl sonlarında başlayarak özellikle 20. yüzyılda ekonomik özerkliği doğurmuş ve en temel yaratı alanının felsefe ve sanattan 
teknolojiye doğru kaymasına neden olmuştur (Birol, 1996). Yaşanan gelişmeler dahilinde ivme kazanan ve günümüzde halen egemenliğini sürdüren teknoloji ve bu paralelde ekonomik yapı, toplumun sosyal yapısı, kültür, sanat ve mimarlık alanlarında çok büyük değişim ve dönüşümlere yol açmıştır.

\subsubsection{Din}

Bilim ve teknolojide yaşanan ilerlemeler, insanların din ve tanrı olgusuna şüphe ile bakmalarına sebep olmuş; yaratılış kanunları ve kutsal kitap mucizeleri yok olmuştur. Aydınlanma ile başlayarak düzenli olarak geliş̧̧ş olan akılcılık 20. yüzyılın ilk çeyreğinde en parlak dönemine ulaşmışır. Bu dönemde insanların ilgisinin başka alanlara kayması, ihtiyaçların değişmiş olması ve yeni ihtiyaçların ortaya çıkması beraberinde yeni yapılanma arayışlarını başlatmışırı.

\subsubsection{Bilim}

20. yüzyılda endüstriyel anlamda yaşanan gelişmeler ile birlikte toplumun yaşam biçimi ve değer yargıları değişim içine girmiştir. Bu süreçte; rüzgâr ve kas gücü yerini; mekanik güç ile çalışan makinalar, elektrik, elektromanyetik, kimyasal hatta daha sonra nükleer enerjiye bırakmıştır. Bununla beraber 20. yüzyıldan önce ulaşım genel olarak insan ve hayvan kas gücüne bağlı iken, 20 yüzyılda ise motorlu taşıt, uçak gibi araçların geliştirilmesi ile ulaşım ve iletişim hızlanmıştır. Ulaşımdaki hızlanma mimarların başka şehirlerdeki hatta ülkelerdeki mimarlardan, mesleki değişim ve gelişmelerden kısa sürede haberdar olmasına olanak tanımıştır. Bu gelişmeler ekseninde yapı malzemelerinin de çeşitlilik bakımından skalası ve kullanım olanakları genişlemiştir; yapı çeliği, alüminyum, beton, cam, ahşap, plastik gibi malzemeler ve prefabrik ürünler geliştirilmiş bu yolla mimarlık alanının imkanları arttırılmıştır. Geliştirilen inşaat araçları sayesinde inşa etme süreleri kısalmış, böylece zamandan tasarruf edilmiştir. Ayrıca elektronik aygıtlarla birlikte yeni yapım yöntemleri ve uzmanlık alanları gelişmiş, bu bağlamda mimari tasarımlarda farklı anlayışlar, esnek, zengin ve özgün yapılar ortaya çıkmıştır.

\subsubsection{Sanat}

Avrupa'da 19. yüzyıl sonlarında sanata olan bakış açısı büyük ölçüde değişime uğramıştır (Süzen, 2018). Sanatın; burjuvazinin tekelinden çıkarak halkın ulaşabileceği seviyeye gelmesi ile tiyatro sayısı artmış, yayın evleri çoğalmış bu sayede edebiyat herkesin ulaşabileceği konuma gelmiştir. Resimlerin ucuz röprodüksiyonlarının üretilmesi sayesinde her eve tablolar girmeye başlamıştır. Fotoğrafın yaygın şekilde kullanıımaya başlanması ile ulaşılamayan görsel sanata ulaşmak kolaylaşmıştır. Ayrıca fotoğraf makinasının icadı sanatçıların ve izleyicilerin bakış açısının değişmesine neden olmuştur. Fotoğraf makinası ile saniyenin çok küçük bir aralığındaki anın durdurulması özelliği, insan gözünün algılayamadığı hızdaki görüntülerin görünmesine olanak tanımıştır (Göktan, 2015). Bu gelişmeler ile görüntülerin fotoğraflanması; ressamların artık görüneni değil, görünmeyeni resmetmeye başlamalarına sebebiyet vermiştir.

Fotoğraftan sonra, sinema da 20. yüzyılda baskın bir sanat dalı olmuştur. Bu sayede öykü, drama, gösteri; zamanın, mekânın ve seyircinin fiziksel doğasının dayattığı kısıtlamalardan kurtularak tüm dünyaya yayılma imkânı kazanmıştır. Sinema ve tiyatronun gelişimiyle, mimari alana sahne tasarımı ve fantastik mekân kurguları yapma olanağı tanınmıştır.

Fotoğraf sanatının gelişmesi, mimari yapı süreçleri ve aşamalarının fotoğraflanmasına, mimarlık tarihinin kayıt altına alınmasına, belgelenmesine, mimarların gidip göremeyecekleri yerlerin ve yapıların fotoğraflarından yararlanmalarına olanak sağlamıştır. Sanatsal gelişmeler teknolojiye bağı olarak fotoğraf ve sinemada geliştiği gibi resim, heykel, müzik gibi alanlarda da kendini göstermiştir. Buna bağlı olarak sanatın mekânsal boyutu olan mimari yapılarda da dönemin sanatsal etkileri yansıtılmıştır.

\subsection{Konstrüktivizm}

20. yüzyıl kapsamında birçok akım ortaya çıkmıştır. Sosyalist gerçekliğin 1917 devrimi sonunda, Rusya'da etkili olduğu dönemde ortaya çıkan ve yaklaşık 10 yıl etkisini yitirmeyen Konstrüktivizm de bu akımlardan biridir. Yeni düzen içerisinde sanatçının; bir mühendis ve bir bilim adamı olduğunu 
savunan bu akıma bağlı sanatçılar, yeni kurulan bir düzenin yeni kurallara ihtiyacı olduğunu savunmuşlardır. Sanat için sanat, gerçeğin yorumu veya tasviri gibi anlayışlara karşı duran konstrüktiviztler; somut bir kaynağı olmayan mühendislik ürünlerini andıran, form bağlamında çarpıcı etkilere sahip eserler yaratmıştır (Şekil 1). Macar sanatçı Moholy Nagy'nin Bauhaus dergisinde çıkmış olan yazısında tekniğe karşı değil, teknikle beraber sloganını kullanarak, tekniği nasıl kullanacağını bilen insanın, onu yerinde kullanabileceğini savunmuştur (Yıldııı, 2018). Nagy'ye göre; endüstri toplumunun yaşamında yer edinen sanatın, yeni sorunlara teknikle birlikte cevap bulması gereklidir. Gelişen teknoloji ile birlikte, sanatta yeni kapılar aralanmıştır. Vlademir Tatlin, El Lissitzky, Mohol Nagy, Georgy Stenberg, Vlademir Stenberg gibi isimler, ürettikleri eserler ile uzay araçları tasarımlarını andıran özgün formlar yaratmıştır. Bu tür eserler; dokunmayla ya da hava titreşimiyle hareket eden kompozisyonlar veya elektrikle çalıştırılarak biçim değiştiren, ses veren, renk ve ışık yansıtan heykel-makine karışımı otomatların yapılmasına ön ayak olmuştur. Bunların ilk örneği Şekil 1 'de verilmiş olan Mohol Naggy'nin 'Işık-Uzam Modülatörü adlı eserdir (Yaman, Ekim, Sungur. ve Özer, 2012).

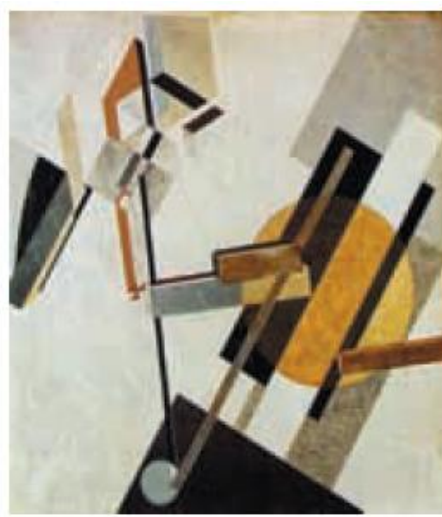

Proun 19 D, El Lissitzky, 1922, Modern Sanat Müzesi, New York

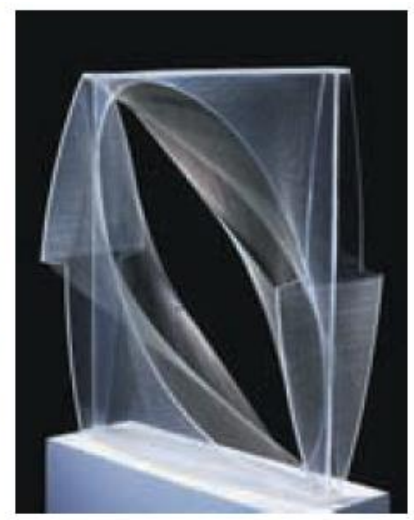

Uzaysal Konstrüktivizm, Naum Gabo, 1943, Amerika Sanat Evi, $A B D$

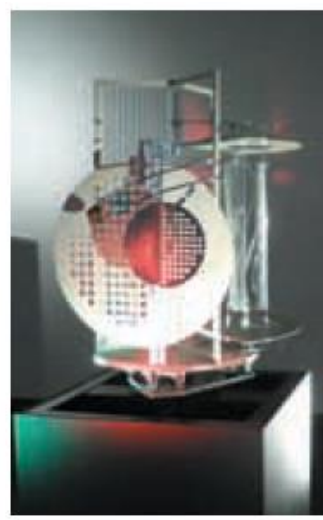

Işık Uzam Modülatörü Moholy Nagy, 1930, Van Abbe Müzesi, Hollanda

Şekil 1: Konstrüktivizm

Konstrüktivizm; sanat için devrim ve Rus devriminin sanatı kabul edilmiştir. Rus devrimi döneminde, Moskova Akademisine profesör olarak atanan Malevich, Tatlin'den devrimi simgeleyen ve Paris'teki Eiffel Kulesi'ne misil olarak bir yapıt istemiştir. Bu isteğe karşılık Tatlin Kulesi adını taşıyan eser yapılmış fakat proje olarak kalmış ve tamamlanamadığından dolayı hayata geçirilememiştir. Yapılan model maket olarak Moskova'da sergilenmiştir. Bu anıt eser; resim, heykel ve mimarinin benzersiz bir kombinasyonu niteliğindedir. Tatlin eserinde; geleceğin uzay çağı dinamizmini yansıtmak amacıyla spiral yapı içindeki silindir, küp ve küreyi rotasyonla hareket ettirmeyi planlamış böylece kinetik heykel ve mimari fikrin öncülüğünü yapmıştır (Şekil 2).

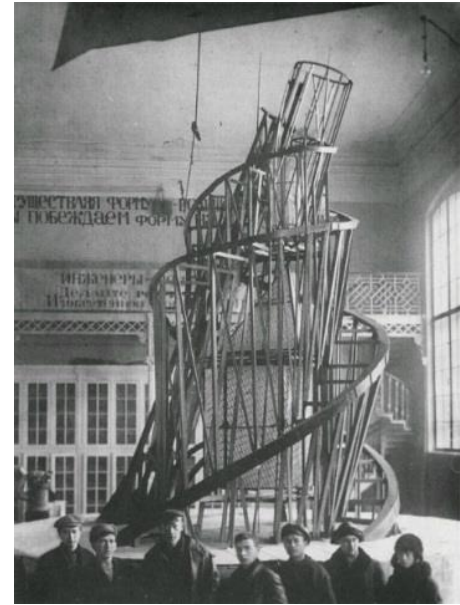

Şekil 2: III. Enternasyonal Anıtı (Tatlin Kulesi)

Moskova'daki Rusakov İşçi Kulübü, Konstrüktivist mimarinin önemli bir örneğidir. 1927-28'de inşa edilen yapı Mimar Konstantin Melnikov tarafından tasarlanmıştır. Kulüp, tabanın üzerinde yükselen 
üç konsollu beton oturma alanı ile yelpaze şeklinde bir plan üzerine inşa edilmiştir. Bu hacimlerin her biri bağımsız tiyatro salonları olarak kullanılabilir ya da bir oditoryum oluşturmak üzere birbirine bağlanabilir. Yapıda kullanılan görünür malzemeler sadece beton, tuğla ve camdır (Architectuul, 2021). Rusakov Kulübü fabrika işçileri için bir tiyatro ve sosyal buluşma yeri olarak tasarlanmıştır. 1927'de inşa edilen yapı, 1920'lerden 1930'ların başlarına kadar Rusya'da gelişen Konstrüktivist stili yansıtmaktadır. Avangard binanın ayırt edici cephesi, Melnikov'un üç büyük galerinin konsollu oturma bölümleri şeklinde merkezi sahne alanından yukarı doğru eğimli olduğu deneysel iç tasarımını yansıtmaktadır. Bu galerilerin her birinde bulunan hareketli duvarlar, farklı oturma ve sahne düzenlemelerine uyum sağlamaktadır (World Monuments Found, 2016). (Şekil 3).

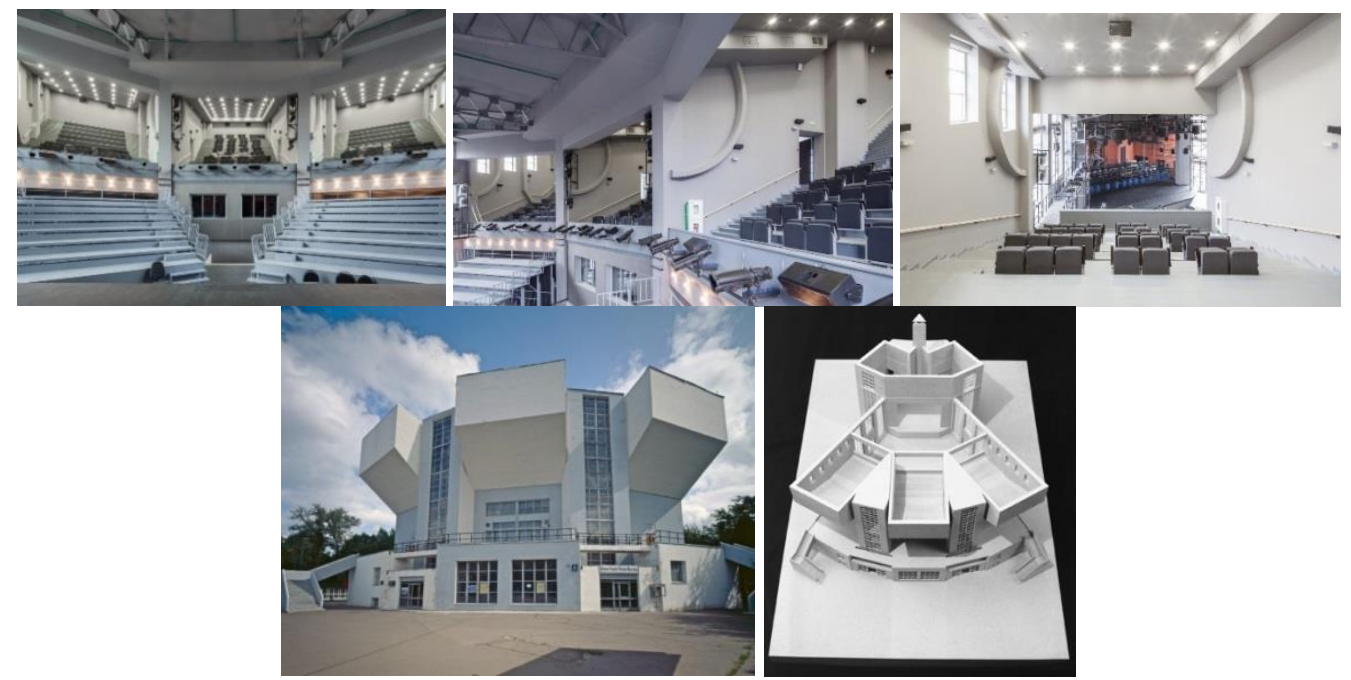

Şekil 3: Konstrüktüvizm mimari yapı örneği: Rusakov Workers'Club / Konstantin Melnikov / Rusya, Moskova, 1927-1929 (Arch365bilgi, 2017; Archdaily, 2011)

\subsection{Bauhaus}

Modernleşmenin tasarımı olarak tanımlanan Bauhaus sanat akımı, bir eğitim hareketinin veya stilin ötesinde, 1850 yılından bu yana Avrupa'da yürürlükte olan ekonomik, kültürel ve toplumsal modernleşme çizgisini ifade etmektedir. 20. yüzyılda sanat alanında en etkili gelişme Bauhaus ile yaşanmıştır. Weimar'da 1919 yılında kurulan okul bir süre sonra kapanarak 1926 yılında tekrar açıımıştır, 1933 yılına kadar da kesintisiz eğitim faaliyetini sürdürmüştür. Bauhaus akımının kalıcı etkisinin temeli, Bauhaus hoca ve öğrencilerinin tasarımlarının sanat eserlerinin ayırt edici özelliği olan soyutlamadır. Bu günümüzde dahi modernliğin temel bir olgusunu temsil etmektedir. Bauhaus'un, zanaattan ayrılıp endüstriyel üretime yönelmesi 1923 yıllarına denk gelse de okul tarihi boyunca nesne ile üretici ve nesneyi yapan ile kullanıcı arasındaki ilişkide, makine üretiminin yarattığı dönüşümlere ayak uydurma çabası vardır (James-Chakraborty, 2019).

Bauhaus, endüstri ile el işçiliği arasındaki farkın, kullanılan aletlerin yapısından çok, endüstride emeğin bölünmesi, el işçiliğinde ise baştan sonuna kadar tek bir kişinin kontrolü altında kalmasından ileri geldiğine inanmaktadır. Bauhaus'a yön veren ilke, sanatta tasarlamanın ne entelektüel ne de maddeci bir olay olduğu, hayatın temel bir parçası olduğuna inanmasıdır. Bauhaus'un felsefesi, "Sanat için sanat" felsefesine tam zıttır. Buna, sanat hayatın vazgeçilmez, organik bir parçasıdır da diyebiliriz (Bingöl, t.y.). Bauhaus akımında temel ilke formun işlevi takip etmesidir. Bu sebeple tasarımlarda genellikle güzellik kaygısındansa; işleve, pratiğe ve kullanışıılığa önem verilmiştir. Bauhaus tasarımlarında süslemenden arınmış, temiz çizgiler, pürüzsüz yüzeyler ve geometrik formların kullanımı öne çıkmaktadır. Mimarı formların iç mekâna yansıması veya içmekanda yapılan tasarımların mekandan taşarak dış kabuğun genel formuna dahil ve adapte olması iç mekan ile dışın bağ kurma çabasını ortaya koymaktadır. Tasarımcılar yeni tasarım anlayışı ile beraber teknolojiyi ve dönemin yeni malzemelerini açık fikirlilikle ve cesurca kullanmışlardır. Bauhaus anlayışı ile ortaya çıkan tasarımlarda yalın, düz hatlı ve işlevselliğin aynı noktada buluştuğu görünmektedir. Açık planlı evler, açık mutfak anlayışı, geniş bant pencereler ve yüzey açıklıkları, çok amaçlı mekanlar, çatı 
bahçeleri ve pilotis kolonların üzerinde yerden yükseltilmiş yapılar Bauhaus ile başlayan modern mimarinin sembolleridir (Dalay, 2020).

Bauhaus denince akla ilk olarak mimarlık gelir ki okul yöneticilerinden üçü de mimardır. Mimar Walter Gropius tarafından tasarlanan ve 1926 yılında Dessau'da açılan okul binası, endüstri ile sanatı birleştiren en çarpıcı yapılardan biri olmaya devam etmektedir (Şekil 4).

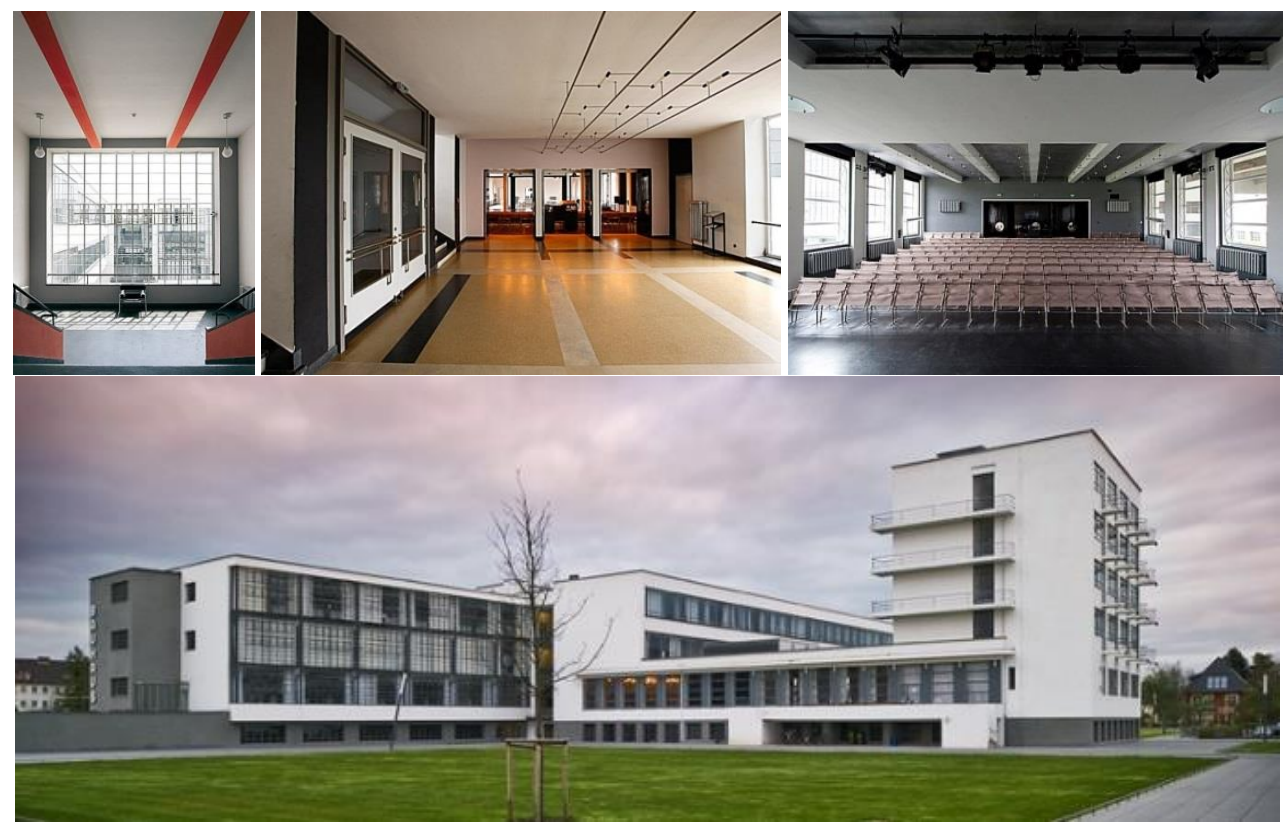

Şekil 4: Bauhaus mimari yapı örneği: Bauhaus Building / Walter Gropius / Almanya, Dessau, 1925-1926 (Bauhaus-dessau, n.d.)

1933 yılına gelindiğinde okul kapatılmıştır, Gropius ve Mies van der Rohe gibi okul yöneticileri ve öğretmenlerinin okul kapandıktan sonra Amerika başta olmak üzere farklı ülkeler gitmeleri ve yapılan reformlardaki rolleri sayesinde Bauhaus adının mimarlık tarihine geçmesine katkı sağlamıştır (Bulat, 2014). Mimarlık ve endüstriyel tasarım konularında etkili olan Bauhaus, şehir planlama konusuna da yenilikler getirmiştir. Yeni bir mimari akım yaratan Bauhaus sanat akımı sanatın bütün dallarını etkilemiştir. Sanat ve zanaat konusunda yaşanan ikilemi ortadan kaldırmaya çalışan bauhaus, teknolojik gelişmeler ile çalışmalarına yön vermiştir. Endüstri, sanat ve zanaat üçlüsünü birleştirmeye çalışan akım, bu birleşimin sağlanması ile en etkili ve en güçlü tasarımların yapılacağını savunmuştur. Bauhaus'un kurulmasındaki temel hedef, kombine mimarlık okulu ve güzel sanatlar akademisi yaratmaktı. Gropious, sanatsal ve fonksiyonel ürünler yaratmak amacındaydı. Çünkü ona göre ressamlık, mimarlık, zanaatkarlık ve heykeltıraşık iç içe olmalıydı. Ayrıca sanatçıyı zanaatkarın en yücesi olarak görmekteydi (Tasarım Akademi, 2018). Yeni tarza yönelik endüstri çağında yaşanan, sanat ile sanatçının rolü üzerinde yapılan bütün çalışmalara öncülük etmiştir. Sanatın bütün parametrelerinin insanların yararına kullanılmasını ilke edinen Bauhaus sanat akımı, herhangi bir ürün tasarımında estetik kaygılar ile içerikten çok fonksiyonuna yönelik olan ihtiyaçlardan hareket edilmesini benimsemiştir. Bu akımın düşüncesine göre, bir şey amacına yönelik tasarlanır ise güzellik de kendiliğinden gelecektir. "Genel olarak akımın tasarım prensibinde şu kurallar göz önünde bulundurulur; toplumsal ihtiyaç, yalın biçimsel arayış, çevre ile uyumluluk, saydamlık hissi ile iç ve dış mekânı birleştirmek ve bu ilkeler bağlamında tasarımı kişisel yaratıcı güç ile ifade etmek (Xoxo Digital, 2018).

\subsection{De Stijl}

Ressam Theo van Doesburg ile mimar Jacobus Johannes Pieter Oud'un 1917 yılında yayımlamaya başladıkları De Stijl dergisi çevresinde toplanan ve özellikle çağdaş mimar ve resim sanatı alanında söz sahibi sanatçıların oluşturmuş olduğu grubun adıdır. De Stijl; resimde Yeni Plastikçilik (Neo Plastisizm) adıyla bilinen akımın destekçisi olmuş, ilkelerini başta mimarlık olmak üzere başka alanlara da uyarlamıştır. Yeni Plastikçilik'in temel amacı; doğadan çıkışlı olmayan bağımsız düzenleme ilkeleri geliştirerek, doğanın rastlantısal formlarının karşısına düzenli geometrik yalınlığa sahip, konstrüktif ve 
işlevsel biçimler getirmektir. Mondrian'ın Kübizm formdaki anlayışından gelen düşünceleri ve bu düşünceleri ileri götüren yapıtlar bu akımın önde gelen örnekleri arasında gösterilmektedir. Bu akımın mimariye uyarlanması ve yansımaları o döneme kadar olan biçimlendirme anlayışlarını derinden etkileyerek yeni değişiklikler getirecek nitelikler barındııı. De Stijl anlayışına birbiriyle dik kesişen kare, dikdörtgen yapı öğeleri ve boşluklar hakimdir. Bunun sebebi ise küp ya da dikdörtgenler prizmasının en yalın biçim kabul edilmesidir. Renk bakımından da yeni bir anlayış hakimdir, renkler salt süsleme öğesi olarak değil aynı zamanda mekânı ve alanları belirleyen önemli tasarım elemanları olarak kullanılmaktadır. Mondrian'ın tablolarında kullandığı kırmızı, mavi, sarı ana renkler ile siyah, beyaz ve gri tonlar kullanılmıştır. Bu renk anlayışı malzeme tercihleri üzerinde etkili olmuştur. Saf renklere sahip olmayan doğal malzemeler ve küçük parçalar ile daha büyük yüzeyleri kapatan tuğla gibi malzemeler görsel olarak sadeliği bozacağı gerekçesiyle kullanılmamıştır. Bu akımın en iyi örnekleri Şekil 5'de verilmiş olan Rietveld'in Utrecht'deki Schroeder Evi ve Oud'un Rotterdam'da yapmış olduğu ve 2. Dünya Savaşında yıkılmış olan De Unie Kahvesi'dir. De Stijl çağdaş mimarlık anlayışının gelişmesine katkı sağlayan önemli akımlardandır. Özellikle dış mekânı iç mekânın bir uzantısı olarak ele alan yaklaşımıyla 1920 'lerin sonuna doğru ağırlık kazanan işlevci mimarlık düşüncelerine hazırlayıcı rol oynayarak ön ayak olmuştur. Pieter Oud ve Gerrit Thomas Rietveld gibi mimarların yapıtları, 2. Dünya Savaşından sonra ortaya çıkan yalın form ve işlevsel mimari yaklaşımları üstünde de etkilerini göstermiştir.

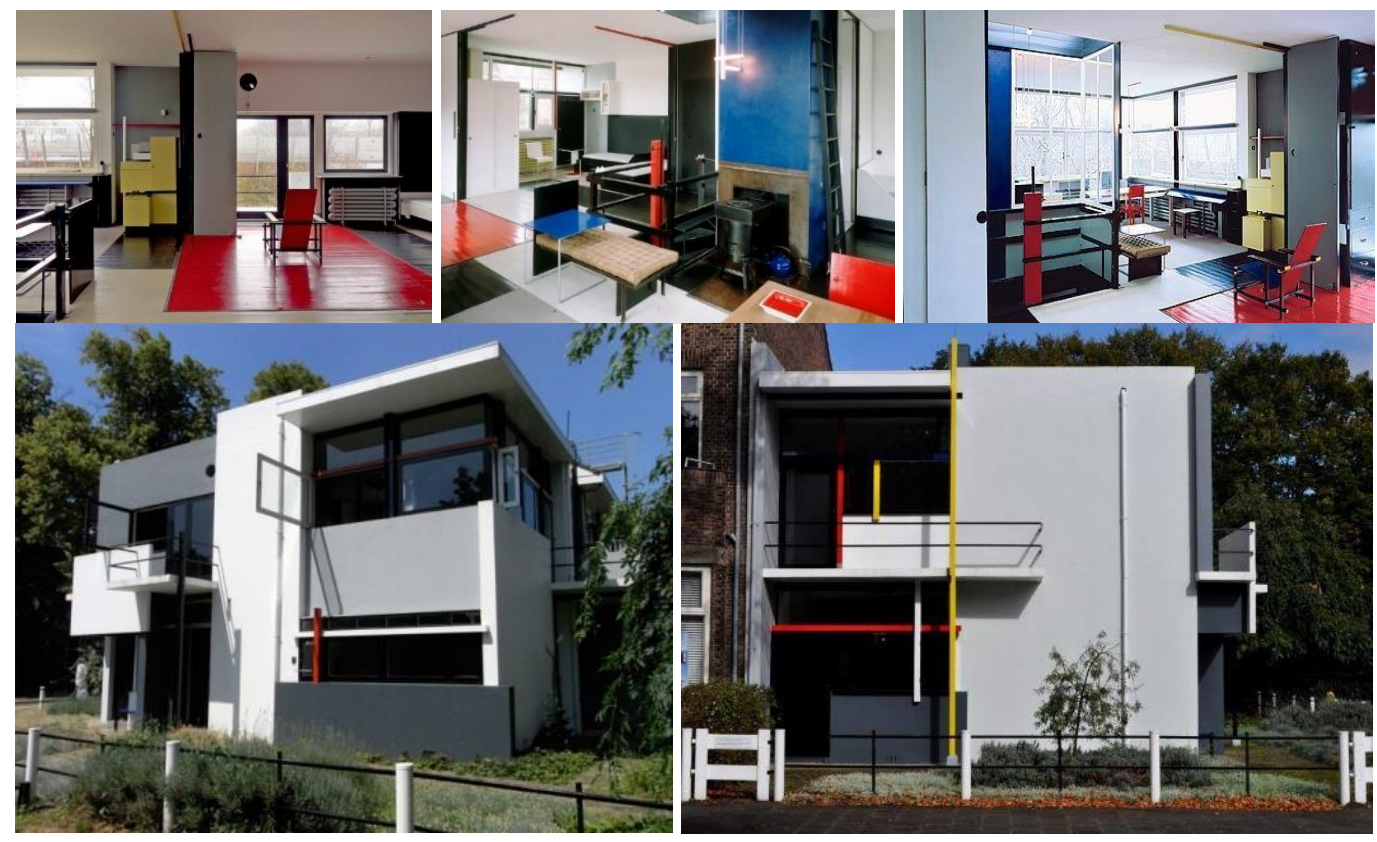

Şekil 5: De Stijl mimari yapı örneği: Schröder House / Gerrit Rietveld / Hollanda, Utrecht, 1924 (Arkitektuel, 2017)

\subsection{Pürizm}

Bu anlayış ilk olarak mimar Le Corbusier ve ressam Amedee Ozenfant tarafından ortaya konmuştur. Kübizm anlayışına karşı olması ile birlikte bu sanat akımının farklı bir varyasyonu olarak bilinen sanat akımıdır. 1918 yılında Le Corbusier ve Ozenfant tarafından After Cubism (Kübizm Sonrası) adında çıkarılan kitapçıkta Pürizm'in prensipleri ifade edilmiştir. Kübizm'in dekoratif görünümlerini elimine ederek; matematiksel düzen, saflık ve mantığın ön plana çıktığı bir sanat anlayışı yakalamak amaçlanmıştır. Şekil 6'da verilen görselde Corbusierin tasarımı olan Notre Dame-du Haunt Chapel bulunmaktadır. Bu tasarımda da görüldüğü gibi yalın ve süslemeden uzak şekilde tasarım ortaya çıkartılmıştır. Pürizmin kritik öğelerinden birisi teknoloji ve makineyi benimsemesidir. Bu da mekânik ve endüstriyel etki bağlamında zamansız ve klasik eserler yaratılmasını sağlamıştır (Sunal, 2016). Geleneksel ve süslemeci mimarlık anlayışı yerine yalın ve işlevsel yapı anlayışını savunur. Püriztler, yalınlığın yoksulluktan ziyade arınmışlığı ifade ettiğini savunmuştur. Sanat yapıtını en aza indirgemiş sayıda öğe kullanarak oluşturma, her tür ayrıntı zenginliği ile renk, teknik ve malzeme çeşitliliğini 
yadsıyan Pürizm, hedeflediği amaçlarla Uluslararası Üslup' un (Enternasyonal Stil) temellerini oluşturmuştur.
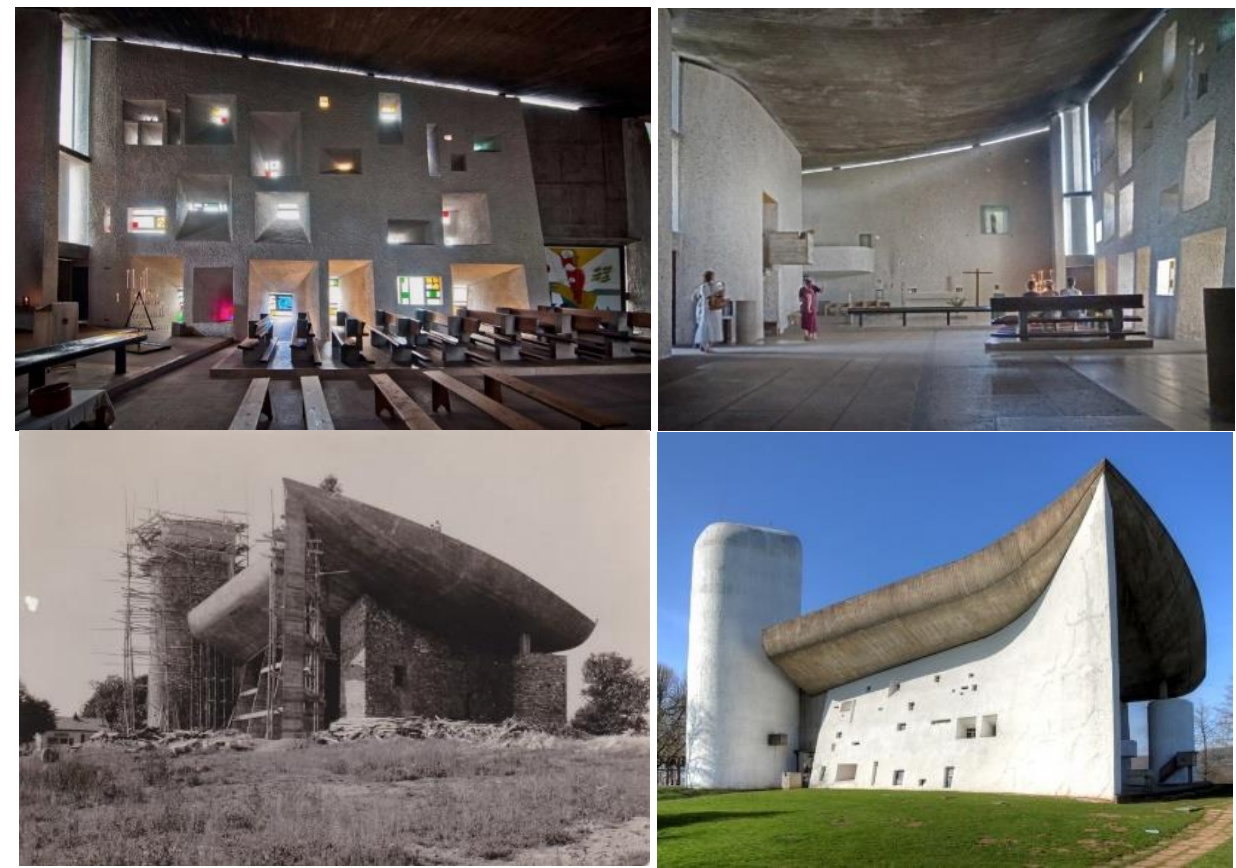

Şekil 6: Pürizm mimari yapı örneği: Notre Dame-du Haunt Chapel / Le Corbusier / Fransa, Ronchamp, 19551954 (Kavrakoğlu, 2014)

\subsection{Modernizm}

Modernizm, mimarlıkta yeni bir estetik görüş oluşturarak süsleme ve bezemeyi kullanmamıştır. Sade mekanlar yaratmayı hedeflemiştir. Soyut geometrik bir biçim dilini benimseyerek; betonarme, çelik, cam gibi malzemeleri sıklıkla kullanmışlardır. Avrupa'da ortaya çıkan akım zamanla evrensel hale gelmiştir. Süslemeden arınmıs, işlevsel yapılar ortaya çıkartma çabası ve bu çaba ile ortaya çıkan ürünler, kısa sürede bütün dünyayı etkisi altına almış ve benimsenmiştir. Modern Mimarlığın temel düşüncesi, gelenekselin zamanını doldurduğudur. Tarihten referans almaktan vazgeçilip özgün bir tasarıma gidilmelidir. Amaç; yeni bir biçim değil, tüm biçimleri yadsıyıp, değişikliğe açık, esnek ve özgün bir mimari tasarım anlayışı yaratmaktır (Erkol, 2009). Çağın mimari anlayışı akıl yürütme süreçleriyle yoktan var edilebilir bir gerçeklik olarak görülüşü, modernist ideolojinin rasyonel bir sisteme yönelmesiyle doğrudan ilişkilidir. Çoğu modern mimarlık ilkesi bu rasyonalist tutumun ürünüdür. Mimarlığın serüveni her türlü toplumsal olaydan ve süreçten etkilenirken, ortaya çıkan değişim bazen ilk olarak mimarlı̆ı̆ kendisinde gözlenir ve sonra topluma yayılır; bazen de tam tersi durum görünür. Toplumsal, teknolojik ya da ekonomik gelişmeler ve değişimler mimarlığı etkileyip değiştirebilir. Bu doğal ve sürekli etkileşim tarihin hemen her döneminde gözlenebilir. Örneğin, Ortaçağ'da skolastik düşünce biçiminin yüceltilmesi ve dinin toplum üzerindeki yoğun etkileri Gotik katedrallerin ortaya çıkışında, Rönesans'ın getirdiği Aydınlanma, sanatın ve mimarinin yüceltilmesinde, Descartes'in getirdiği rasyonalist düşünce biçimi 17. Yüzyılda pozitif düşüncenin ve teknolojik gelişmelerin başlamasında ve modernleşmenin temellerinin atılmasında, buharlı makinelerin bulunması, tarım toplumunun endüstri toplumuna dönüşmesinde ve bu gelişmenin sanatı ve mimariyi de dönüştürmesinde etkili olmuştur (Birol, 2006).

19. yüzyılın son zamanlarında ortaya çıkan Arts and Crafts ve Art Nouveau yaklaşımları, sanat ve mimariyi klasik anlayıştan yalıtan bir tutumun ortaya çıkmasına ve gelişmesine altyapı hazırlamıştır. Özellikle Art Nouveau, endüstri devriminin yaşanmakta olduğu dönemde teknolojik gelişmelere adapte olarak eklektik ve revivalist yaklaşımlarla tarihsel üsluplara atıfta bulunularak üretilen mimari yapıların yerini giderek daha yalın ve doğadaki biçimlerden esinlenerek tasarlanmış yapılara bırakmasına neden olur. Bu gelişme 20. yüzyılda mimarlık alanında tarihsel biçimlerin egemenliğinden sıyrılmış, ortaya çıkan yeni yapı malzemeleri ve yapım yöntemlerini benimsemiş, 
çağdaş ve yalın, yeni mimari düşüncenin, modern mimarlığın kapılarını aralamıştır. Dahası bu tutum, gelecekte modern mimarlığın en önemli ilkelerinden biri haline gelecektir (Özyalvaç, 2013).

19. yüzyılın sonlarında ortaya çıkan çağdaş ve yalın mimari anlayış, 20. yüzyıla gelindiğinde mimaride ve bununla birlikte plastik sanatlarda hızla gelişmeye, yayılmaya başlamıştır. Mimaride Adolf Loos, Tony Garnier ve Auguste Perret, Art Nouveau ile başlayan yalınlaşmayı daha da ileriye taşıyarak Erken Modernizmin temellerini atmışlardır. Adolf Loos, Kültürün evrimi, kullanıma dönük nesnelerin süslemeden arındırılması ile eşanlamlıdır. Süsleme suçtur. Süslemenin ötesine geçtik, düz, bezemesiz yalınlığı gerçekleştirdik (Loos, 2014) diyerek yapının simgesel değerini reddederek, yalınlığı yüceltmiştir.

Endüstri devriminden bu yana ulaşılması hedeflenen modern mimarlığın idealleri, bu yaklaşımla birlikte mimarlık düşüncesinde tam anlamıyla hâkim olmuştur. Mimarlık alanında sıklıkla vurgulanan; teknolojinin önemi, kullanılan yalın geometrik formlar aracılıyla sağlanacak mutlak soyutlama, biçimde sadelik ve mekânda işlevsellik arayışları bu dönemde rasyonel ve pürist bir mimarlık anlayışı ortaya koymaktadır. Modern akımın klasik dönemi olarak sayılabilecek Uluslararası Üslubun önemli temsilcileri Le Corbusier ve Mies Van der Rohe modern anlayışın en önemli mimarları olarak kabul edilir. Projelerinde benimsemiş oldukları ve uyguladıkları kriterler zamanla modernizmin kurallarına dönüşmüştür. Bu nedenle Modern Mimarlıktan söz edildiğinde akla ilk olarak bu iki isim gelmektedir. Modernist mimarinin; kendinden önceki tarihi tarzlara karşı çıkan bakışı, sadelik ve işlevsellik üzerine kurulu yapı anlayışı, rasyonel endüstriyel üretim çağına ait bir mimari yaratma arzusu, politik duruş gibi özellikleri modernist hareketin mimarlık tarihindeki etkilerini yansıtan özellikleridir (Mays, 2006).

Mies van der Rohe, tasarımlarında biçimi ele alışını, daha doğrusu reddedişini şu sözlerle ifade eder: "Bizim için biçim yok, sadece inşa problemleri var. Biçim amaç olarak değil, çalışmamızın bir sonucu olarak var. Sadece form amaçlı üretilmiş form yok. Formun amaç haline gelmesi biçimciliktir ve biz bunu reddederiz. Bir stili de amaçlamıyoruz. Stil kaygısı da biçimcidir. Bizim başka kaygılarımız var. Biz öncelikle, yapıyı estetik spekülasyonlardan kurtarıp özgürleştirme, yapıyı sadece yapı olarak ele alma motivasyonuna sahibiz." (Akt. Erkol, 2009)

Modern Mimarlığın öncülerinden olan Frank Lloyd Wright tarafından tasarlanan Fallingwater/Şelale Evi, dünyanın en önemli modern mimari projelerinin başında gelmektedir. Frank Lloyd Wright'ın en önemli eserlerinden biri olarak kabul edilen Şelale Evi, dünya çapında ilham kaynağı olmayı başarmıştır (Şekil 7).

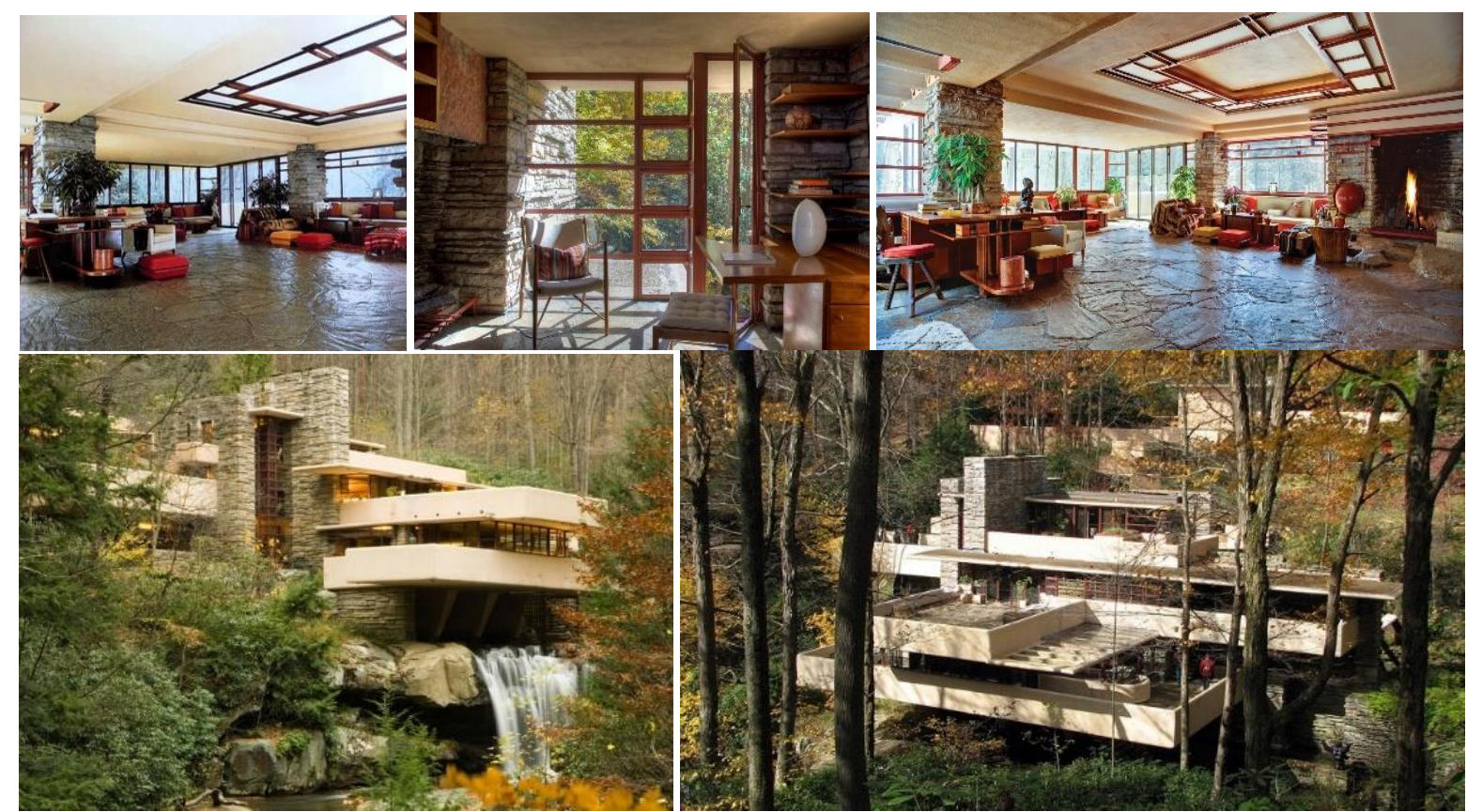

Şekil 7: Modern mimari yapı örneği: Fallingwater house / Frank Lloyd Wright / ABD, Pensilvanya-Mill Run, 1935 (Arkitektual, 2017) 


\section{7. İç Mekan ve Form}

\subsubsection{Mekân Tasarımı ve Mekân Örgütlenmesi}

Mekân, insanlar ile ilişkisi bakımından ele alındığında toplumsal bir üründür ve tarihsel süreç içerisinde oluşmaktadır. Tarihi süreçte gerçekleşen tarımsal, endüstriyel ve sanatsal gelişmeler ile beraber değişime uğramaktadır. Mekân, kullanıııyı nasıl etkiliyorsa, toplum-insan paralelinde gelişen ilişki ve intiyaçlar da mekân tasarımını o derece etkilemektedir. İç mekân tanımlarken kesin sınırları olan bir alandan bahsedilmelidir. Dolayısıyla iç mekân; dış dünyaya karşı korunma ihtiyacı ve duygusu ile etrafı sınırlandırılmış, kullanıcının sosyal, kültürel ve toplumsal ihtiyaçlarını karşılayan yer olarak tanımlanabilir. İç mekân, ilk olarak tasarlanan yapının strüktüründen yola çıkarak oluşturulan zemin, duvarlar ve tavan düzlemleriyle sınırlandırılır. Sonrasında pencere ve kapı gibi açıklıklar sayesinde diğer iç veya dış mekânlar ile ilişki kurulur. Tasarlanan mekânların formu, yüzeylerden oluşur. Yüzeyler mekânda zemin, duvarlar ve tepe yüzeyi olarak karşımıza çıkar. Düz-eğrisel, girintili-çıkıntılı, dolu-boş, uzun-geniş vb. özellikleri ile farklıık gösterirler. Mimari tasarımlarda önemli bir eleman olan yüzey, hacmin sınırlarının tanımlanmasını sağlar.

Mimari yapıyı taşıyan ve destekleyen zemin yüzeyi, coğrafik yapı ve arazı koşullarına bağıı olarak yapı biçimini ve formunu etkiler. Yapı; zemin yüzeyi ile iç içe geçebilir, bulunduğu zemin üzerine oturabilir veya onun üzerinden yükselebilir. Yükseltilmiş bir düzlem olan döşeme yüzeyi, zemin yüzeyinin üzerini kaplayan, mekân içerisinde bulunan nesnelerin ve kullanıcıların ağılığını taşıyan yatak yüzeydir. Ayrıca renk, doku, form özellikleri ile mekânı sınırlayarak kullanıcıya hizmet eder. Mekânın iç ve dış sınırlayıcı görevini duvar yüzeyi yerine getirir. Mekânların tanımlanabilmesi için dış ve iş duvarlara ihtiyaç vardır. Duvar yüzeyleri özellikleri bakımından farklılıklar gösterir. Dış cephe duvarları iç mekânı sınırlayan, kalın ve ağır duvarlardır. İç mekânın bölücü duvar yüzeyleri ise; ince, hafif yer yer saydam duvarlar olarak karşımıza çıkar. İ̧̧ ve dış mekân arası geçiş ise kapı ve pencere açıklıkları ile sağlanır. Duvar yüzeyi, yapı strüktürü bünyesinde taşıyıcı, destekleyici ve bölücü vazifesi görebilir. İç mekân duvarları genelde mekândaki alanları sınırlayan, mahremiyeti sağlayan, tavan yüzeyi ve döşeme düzlemini birbirine bağlayan, kullanıcıyı yönlendiren yapı elemanlarıdır. Dış duvarlar ise, iş mekânı dış çevreden yalıtarak denetlenebilir bir iç alan yaratır. Öte yandan dış duvar yüzeyindeki açıklıklar sayesinde dış çevre ile gerekli bağlantı yeniden kurulmuş olur. Bu yüzeylerin iç mekânı sarması ile dış mekânı kendiliğinden şekillenerek binanın genel biçimini ve kütlesini tarif ederler (Ching, 2007). Tepe yüzeyi gök kubbeyi simgeler. Bu yüzey sayesinde kullanıcı kendi boyu ile mekân arasında oransal bir kıyaslama yapabilir. Tepe yüzeyi yapının formunun belirlenmesinde etkilidir. Farkı geometrik hareketlerde, eğrisel, girintili çıkıntılı formlarda tepe yüzeyleri oluşturmak mümkündür. Yapının genel formunu belirlemede etkili olan bu yüzey ayrıca mekânın akustik ve aydınlatma gibi intiyaçlarına bağlı olarak da şekillenebilir. İç mimaride form, çevrenin ve mimarinin temel özelliklerini yansıtacak, görsel manada vurgulu ve işlevin gerekliliklerini yerine getirecek tarzda örgütlenmesi gerekmektedir.

\subsubsection{Mekânın Algılanması}

Birey iç mekânda bulunan formlara ve mekân biçimine göre devinimi ile mekân algısı oluşmaya başlamaktadır. Mekân algısı, bireyde ilk olarak kullanım ve işlev olarak kullanıcı ile ilişki kurarken, sonrasında mekânın tasarım özellikleri bakımından bireyde farklı duygular açığa çıkar. İç mekân algısı fiziki etmenler aracılığı ile oluştuğu gibi sadece görsel unsurlar ile de oluşabilmektedir, renk ve ışık fiziksel bir form oluşturmamasına karşın bir mekânı belirtebilir ve mekân algısı yaratabilmektedir. Bu algı, bireyin mekân içerisinde geçirdiği zamana ve edindiği deneyimler sonunda kazanmış olduğu mekânsal verilerdir. Edinilen veriler görme algısı ağırlıklı olmasına karşın, diğer duyularda önem teşkil etmektedir, çünkü mekân algısı bütün duyuların çeşitli oranlarda edindiği bilgilerin birleşmesi ile oluşmaktadır (Alici ve Göker Paktaş, 2020).

\subsubsection{Formun Öğeleri ve Mimari Form Türleri}

Fiziksel ve/veya kavramsal olarak tanımlanabilen formu Doğan Hasol; "nesnenin ve boşluğun genel düzeni" olarak açıklamıştır (Hasol, 2002). Form, mekânda anlam ifade eden düzen, biçim, malzeme, renk, doku gibi öğelerin, birbiriyle ilişkileri sonucu algılanır (Thurell, 1989), uzayı yüzeyleriyle sınırlar 
ve uzay içinde bir hacim kaplar. Formu tasarlama olanağı tanıyan form öğeleri ile zihinsel formun yansıması şu öğeler ile yaratılabilir; nokta, çizgi, yüzey, hacim ve kütle. Bunlara kısaca değinecek olursak şu şekilde açıklayabiliriz.

Nokta: Gözün algı sınırları içinde bulunan en küçük tanımlı ve boyutsuz öğe olarak açıklanabilir. Nokta özellik olarak basit, yön ifade etmeyen, açısız, daire olarak kabul edilir. Nokta; kare üçgen, oval ve tanımsız formlardan da oluşabilir (Wong, 1972).

Çizgi: Gözün gördüğü tek boyutlu uzunluk sembolüdür (Atalayer, 1995, Akt. Kaptan, 1997). Çizgi, yüzeylerden meydana gelmiş üç boyutlu formlarda görünür, iki yüzeyin birleştiği yeri ifade eder. Çizgi formu anlatmak için; akıcı-keskin, yumuşak-sert, kalın-ince gibi etkilerle formun ışık değerini göstererek ortaya çıkartır.

Yüzey: İki boyutlu görünüş yüzey olarak adlandırılır. Derinliği olmayan, en ve boy olarak algılanan formlardır. Uzayda bir formun tanımlanabilmesi için koordinat sisteminde en az üç noktanın olması gerekmektedir. Nokta veya çizgi olarak algılanmayan bütün yassı formlar yüzey olarak tanımlanır (Wong, 1972).

Hacim ve kütle: En, boy ve yükseklik olarak tanımlanabilen her şey üç boyutlu elemandır. Bu bağlamda bulundukları yerde alan kaplar, belli bir üç boyutlu alanı hapseden sınırları ve hacmi bulunur, bu hacim o elemanı tanımlayan bir özelliktir. Yer kaplayan ve hacmi olan elemanlar, yoğunluk ve ağırlık ifadesi ile tanımlanabiliyorsa kütlesi olduğu anlamına gelir. Kütle, uzay içerisinde bulunan formun yoğunluğu ve ağırlığı ile ilişkili bir kavramdır (Enstice ve Peters, 1990). Hacim ise, formun uzay içerisinde kapladığı ve sahip olduğu üç boyutlu alandır.

Üçüncü boyuta çıkan form kavramı her alanda olduğu gibi mimarlık alanında da çeşitlilik gösterir. Dolayısıyla mimari form türleri şu şekilde sıralanabilir;

İ̧̧ ve Dış Formlar: Herhangi bir formun yüzey biçimi dışa doğru oluşmuş ise dış form olmuş olur. Bu yolla formun örttüğü alanın içinde de mekân örgütlenmeleri oluşabilir, buna da iç form denir. Dış bükey ve iç bükey olarak iç ve dış formlar birbirinin tersi olabilecek yapıya sahip olabilir (Şekil 8).

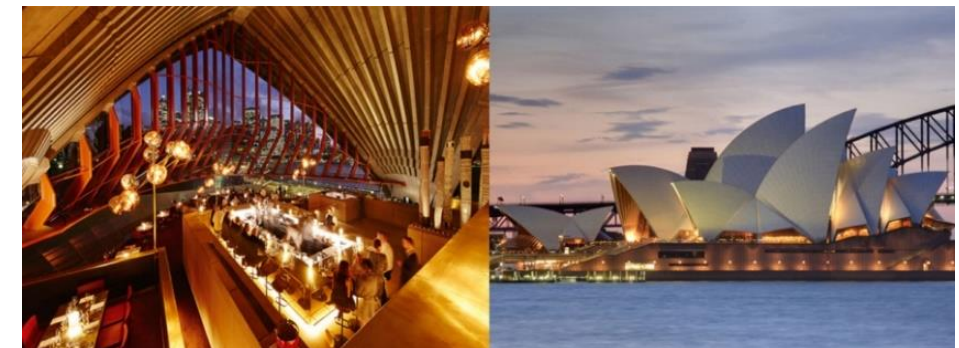

Şekil 8: İç ve dış formalar. (Sidney Opera Evi, Mimar: Jorn Oberg Utzon)

Pozitif ve Negatif Formlar: Kütlesel olarak uzayda yer kaplayan, hacmi olan formlara pozitif formlar, aynı uzayda bulunan boşlukların tanımlanmasına ise negatif formlar denir. Pozitif ve negatif formlar birbirini tamamlayan, bir bütünü oluşturan zıt parçalardır. Bu formların örgütlenmesi ile iç mekânda kullanım alanlar ve sirkülasyon boşlukları meydana gelir (Şekil 9).

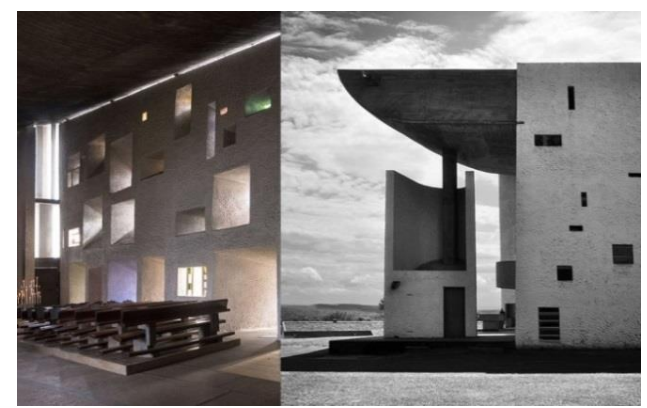

Şekil 9: Pozitif ve negatif formlar (Notre Dame du Haut, Mimar: Le Corbusier)

Statik ve Dinamik Formlar: Hareketsiz, sabit ve durağan hissi veren formlar statik formlardır. Mısır piramitleri bu forma iyi örnek olacaktır. Taban alanının genişliği, olası bir yıkılma veya devrilme 
durumunu ortadan kaldırmakta ve dengeli bir görüntü yansıtmaktadır. Değişim ve dönüşümü, enerjiyi, hareketi yansıtan formlar dinamik formlardır.

Kapalı ve Açık Formlar: Kapalı form, bir form örgütlenmesinin başka elemanlarla çevrelenmesi sonucu oluşan kompozisyondur. Kapalı formlar biçimsel olup yapıyla ön plana çıkmaktadır. Açık form, hareket ve zıtlıklar formun ilgi çekiciliğini arttırmaktadır. Formda devam etme, tekrar, ritim ilkeleri gözlemlenir (Şekil 10).

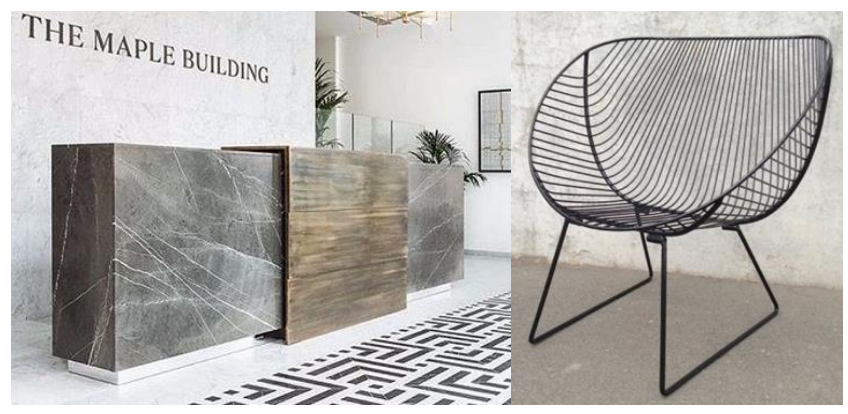

Şekil 10: Kapalı ve açık formlar

Soyut ve Somut Formlar: Soyut formlar, üç boyutlu olarak var olan formların oran-orantı, ölçü benzeri fiziksel özelliklerinden yola çıkarak, tasarımcı veya sanatçının elinde farklı bir anlam kazanması sonucunda meydana gelir (Zelanzki ve Fisher, 1987. Akt. Kaptan, 1997). Somut formlar, üç boyutlu uzayda var olan formlardır.

Organik ve İnorganik Formlar: Canlı organizmaların hücresel yapısına uygun formlardır. Düzenin monotonluğuna karşı yaşamı temsil eden formları tanımlar. Organik formlar, birlik ve bütünlüğün devinim egemenliğindeki yansımasıdır. İç mekânlarda daha çok eğri ve dairesel formların örgütlenmesi ile tasarıma yansımaktadır. Alvar Aalto ve Frank Lloyd Wright'ın benimsemiş oldukları organik form anlayışı Gotik dönem ve 20.yy ilk çeyreğinde yapılan iç mimari tasarımlarda kullanılmıştır.

İnorganik form; köşeli, prizmatik, cansız ve durağan formlardır.

\subsubsection{Mimari ve İç Mimari tasarımda Form, Formlar Arası İlişkiler}

Mimari ve iç mimari tasarımlarda form, biçim, kurgu birbirini sürekli takip eden ayrılmaz öğelerdir. Bu öğelerden olan formun iki işlevi bulunur. İlki, somut hacmi oluşturan sınırlar, hareketli ve hareketsiz mobilyalar. íkincisi ise bireylerde oluşan imgeler ve bu süreçte oluşan algılamadır. İç mimarlıkta, yaratıcı süreçte evrensel formlar kişisel görüşler çerçevesinde düzen kavramı ile geliştirilir. Düzen, biçim ve öğelerin birbirleriyle olan ilişkisi formu belirler. Yani; malzeme ve detayların kullanımı veya öğelerin nasıl düzenlendiği formun anlamını, amacını ortaya koyar (Aydınlı, 1993).

Form çeşitlerinin bir arada kullanımı ve ayrı tip formların birbiri ile ilişkiye girmesi sonucunda ortaya özgün formlar çıkabilmektedir. İki boyutlu ve/veya üç boyutlu formlarda kütleler ve hacimler farklı algılara sahip olabilmektedir. Formların kendi aralarında oluşturdukları ilişki sekiz farklı başlıkta sıralanabilir (Wong, 1972).

Kopma: Formların birbiri ile ilişkiye ve etkileşime girecek kadar yakın mesafede yer alıp, ancak birbirine değmemeleri durumudur. (Şekil 11 - Görsel: a)

Değme: En az iki formun etkileşime girecek kadar yakın olması ve birbirine dokunmalarıdır. Ancak birbirinin kapladıkları alanlara girmemektedirler, sınır konturları ile birbirine dokunmaktadırlar. (Şekil 11 - Görsel: b)

Üst üste gelme: İki form birbiriyle etkileşime ve ilişkiye girecek kadar iç içedir. Bir form diğerinin kapladığı alanı örterek üste çıkmaktadır. İkinci formun örtünen kısmı arkada kalmaktadır. (Şekil 11 Görsel: c)

iç içe girişme: Şeffaf iki formun içe geçmesi ve iki formun da sınırlarının görünmesi durumudur. Örtme ve ön-arka durumu yoktur. i̇ki formun oluşturmuş olduğu ortak alan çıkarılmış yeni bir form oluşmuştur. (Şekil 11 - Görsel: d) 
Birleşme: iki formun birbiri ile tek bir formmuş gibi birleşerek yeni bir form oluşturmasıdır. Büyük ve yeni bir form oluşmuş olur. (Şekil 11 - Görsel: e)

Çıkarma: Iki formun üst üste gelme yöntemiyle ilişki kurması ve bir formun kapladığı alan kadar diğer formdan eksiltme yapmasıdır. (Şekil 11 - Görsel: f)

Kesişme: iç içe girişme ile aynı şekilde gerçekleşir fakat bu yöntem de kesişen kısımlar formun kendisini oluşturur. (Şekil 11 - Görsel: g)

Denk gelme: iki formun sınırlarının birbirine denk gelecek şekilde örtüştürülmesidir. Bu da yeni formun tek bir formmuş gibi görünmesini ve algılanmasını sağlar. Bu yöntemlerin tek başına veya birkaçının birlikte kullanımı ile yöntem sayısı arttırılabilir ve tasarım olanağı genişletilebilir. (Şekil 11 Görsel: h)

a
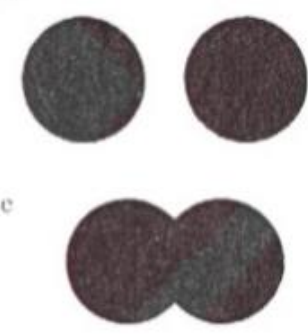

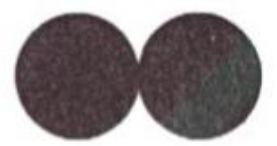

f

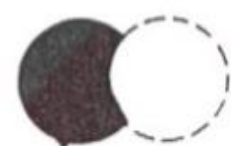

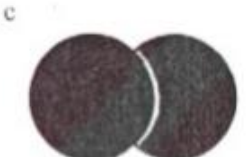

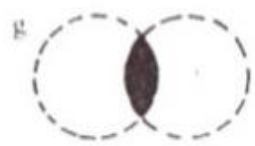

d

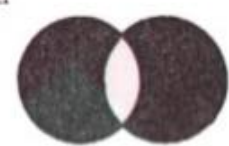

h

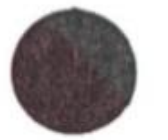

Şekil 11: Form ilişkileri çeşitleri (Wong, 1972)

\subsubsection{Formun İç Mimari Mekânda Örgütlenme Prensipleri}

İç mimari mekân tasarımında kurulacak düzen ve bu düzeni sağlayacak ilkeler, mekânın öğeleri, formu ve bu formların; doku, biçim, renk gibi yapısal özelliklerini etkilemektedir. Bu ilkeler tek başlarına uygulanmasından ziyade birlikte kullanımlarında doğacak sonuçları ile daha etkili ve sonuca yönelik olmaktadır.

Tekrar: Birbiriyle ilişkili biçimde kullanılan benzer biçim, form, ölçü, renk, pozisyon ve dokuların oluşturduğu örgütlenmedir. Formun örgütlenmesi sırasında tekrarın kullanılması monotonluk yaratabilir. Bu sebeple tekrarın kullanılması durumunda yön değişikliği, üst üste gelme, iç içe girişme, kesişme, değme gibi ilişki çeşitlerini kullanarak uyum ve düzen oluşturulabilir (Wong, 1972). İ̧̧ mekânlarda tekrar yolu ile örgütlenen formlar, bir ritmi oluştururlar. Bu formların birlikteliğinde uyum, zıtlık gibi ilkelerin kullanımı, yaratılmak istenen atmosferin kurgulanmasına ve monotonluktan kurtulmasına yardımcı olabilir.

Uyum: Formları meydana getiren parçaların birbiri ile olan benzerlik ve uygunluğudur. Fiziksel özelliklerde uyum olacağı gibi işlevsel ve anlamsal olarak da olabilir. Bu bağlamda Atalayer, birbirine ait olduğu hissini veren unsurlar ahenklidir demiştir (Atalayer, 1994).

Zıtlık (Kontrast): Formlar arasındaki renk, ton, doku, biçim, ölçü, yön gibi özelliklerle zıtlıklar yaratmak mümkündür. Bu değişkenlerin çeşitli açılarda zıtlıklar oluşturması ile de bir bütünlük yaratılabilir. Örneğin, üçgen ile kare bir form birbirine benzememelerine karşın komşu iki formdur. Eğri konturlardan oluşan bir form bu iki form için uzlaşmaz bir ilişki içinde olabilir. Form olarak uzlaşan ya da uzlaşmayan zıtlıklar ölçü, renk, doku gibi diğer etmenler içinde geçerlidir. Zıtlıklar, uyum ve tekrar gibi ilkelerden daha çabuk algılanır ve bireyi daha hızlı uyarır (Kaptan, 1997).

Hiyerarşi: Formların birlikteliğindeki düzen ve dengedir. Ayrıca zıtlıkların uygun geçişler ile birbirine bağlanması, ilişki kurmasıdır denebilir. Kar tanelerinin yapılanışı, deniz kabuklarındaki sarmal hareketlerin birbirini takibi veya ağaçlarda büyük dallardan küçük dallara oradan yapraklara gerçekleşen geçiş formlar arası hiyerarşik düzeni örneklemektedir. Belirli oranlar ile formların değişmesi, tekrarı ve renk, doku, ton, yön gibi yapısal özellikler ile kurulan ilişkideki düzen hiyerarşiyi oluşturur.

\section{Bulgular}


1920-1945 dönemi; keşifler, buluşlar, sanatsal ve bilimsel gelişmeler ile birlikte savaşların yaşandığı bir dönem olmuştur. Bu gelişmelerin ve toplumsal, sosyal yaşantının etkileri ile çeşitli akımlar ortaya çıkmıştır. Bunlar; Konstrüktivizm, Bauhaus, De Stijl, Pürizm ve Modernizm olarak sıralanabilir. Akımlar sanat ve mimarlıkta baskın şekilde hissedilirken, mimari ve dolayısıyla iç mimaride ağırlıkı olarak form ve biçim farklııkları şeklinde göze çarpmaktadır.

Konstrüktivizm 1920-1945 döneminin başlarında ortaya çıkmışır. Bu akımda mekânik bir güzellik anlayışıyla birlikte form olarak strüktürel dinamizm öne çıkmaktadır. Genellikle somut kaynağa sahip olmayan mühendislik ürünlerini çağrıştıran güçlü formlar kullanılmıştır. Bu bağlamda kullanılan formların etkisini artırmak için yapılarda parlak ve canlı renkler kullanılmıştır.

Alman mimar Walter Gropius tarafından kurulan Bauhaus Okulu 1926 yılında, daha önce açılıp kapanmasının ardından, ikinci sefer açılmıştır. Bu okulun kuruluş amacı; mimarlık, sanat, endüstriyel tasarım ve zanaatı birlikte alarak yeni bir tasarım, üretim ve sanat anlayışı ortaya çıkarmaktı. Bu okul kendi dönemine büyük etki yaparak tüm dünyaya yayıldı ve kabul gördü ve günümüzde hala etkisi devam etmektedir. Bu dönemde genel olarak düz hatlı kübik formlar kullanılmıştır. Formların öz görüntüsüne çok fazla müdahale edilmeden ve bozmadan kullanmaya özen gösterilmiştir. Bu dönemin önemli bir özelliği de yapılarda kullanılan malzeme seçimleridir. Genel olarak cam malzeme ön planda olup mekânlar saydam bırakılarak sağlam bir iç-dış mekân ilişkisi kurulmuştur. Bauhaus döneminde form olarak yakalanan sadelik, renk seçiminde de kendini göstermiş ve renk en aza indirgenmiştir. Akımlar sırayla ele alınsa da tam bir sıralamaya sokmak yetersiz kalabiliyor. Belli akımlar bitmeden başka bir akım başlayabilmekte veya bitmiş bir akım yeni akımla beraber tekrar canlanabilmektedir. Gelişmelerin hız kazandığı 1920-1945 yılları arasında mimarlık ve güzel sanat dallarında ortaya çıkan akımlardan biride De Stijl'dir. Bu akım ile basit dik köşeli formlar ve asimetrik kompozisyonlar tercih edilmiştir. Genelde akromatik renklerin tercih edildiği bir akım olan De Stijl'de renkliliği sadece ana renk olarak detaylarda görmekteyiz.

Fransız Ressam Amadee Ozenfant ve Mimar Le Corbusier tarafından ortaya konmuş bir sanat akımı olan Pürizm'de, süsleme reddedilerek temiz ve net hatlı form seçimleri amaçlanmıştır. Pürizm, arıtılmış ve birbiriyle ilişkili öğelerin birleşmesi olarak ifade edilebilir. Bu bağlamda iç mekânlarda geometrik ve tamamen yalın hatlı form biçimleri kullanılmıştır. Modernizm, temel olarak biçimin basitleştirilip yalınlaştırılması ve süslemenin mimari yapılarda yok edilmesi gerektiğini kendine ilke edinen bir ekoldür. Dünyada pek çok saygın mimar, tasarımcı ve eğitimci tarafından kabul görüp popüler hale gelmiştir. Bu akımda form olarak statik, geometrik, kübik formlar tercih edilmiştir. Sağır, şeffaf ve düz yüzeyli yalın biçimler öne çıkmaktadır.

\section{Sonuç}

Sanatsal akımlar, mimari akımların ortaya çıkmasına sebep olmuş böylece mimarlık tarihi çeşitli dönemlere ayrılmıştır. Mimari akımlar; ortaya çıktıkları dönemin sanatsal hareketliliği ve anlayışı, toplumun sosyal ve ekonomik yapısı, dini inançları, siyasi ve bilimsel gelişmeler gibi etmenlerden etkilenerek ortaya çıkmaktadır. Bu akımlardan bazıları gelişme göstererek dünyaya yayılmış, bazıları ise zamanla zayıflayarak yok olmuş veya başka bir mimari anlayışa evrilmiştir. 20. yüzyılda meydana gelen gelişmeler, olaylar, savaşlar dinamizmi arttırarak sanatsal ve bilimsel çalışmalara katkı sunmuştur. Savaşların ve toplumsal çatışmaların mimariye ise zararları olmakla birlikte, sanat ve bilim alanlarında yaşanan gelişmeler mimarinin estetik ve teknik anlamda gelişmesine katkı sağlamıştır.

Bu yüzyılda yaşanan teknolojik gelişmeler iletişimi hızlandırmıştır. Dolayısıyla iletişimi artan toplumlar birbiriyle daha çok etkileşime geçmeye başlamış ve sanatsal, kültürel, bilimsel vb. alanlarda daha hızlı aktarımlar, gelişmeler yaşanmıştır. Bu durum aynı zaman aralığında var olan sanat anlayışlarının birlikte yaşamasına, birbirini etkilemesine, geliştirmesine ve yeniliklerin ortaya çıkmasına katkı sağlamıştır.

Tarihi süreç içerisinde iç içe geçmiş olan akımlar olduğu gibi mimari yapılarda da bu etkiler görülebilmektedir. Mimari akımların farklııklarla birlikte benzerlikleri de bulunmaktadır. Bu bağlamda mimari eserler incelenirken tek bir akım içinde kalmayıp farklı akımların etkilerinin de olduğu gözlemlenmektedir. 


\section{Teşekkür ve Bilgi Notu}

Makalede ulusal ve uluslararası araştırma ve yayın etiğine uyulmuştur. Çalışmada etik kurul izni gerekmemiştir.

\section{Yazar Katkısı ve Çıkar Çatışması Beyan Bilgisi}

Makalede tüm yazarlar aynı oranda katkıda bulunmuştur. Herhangi bir çıkar çatışması bulunmamaktadır.

\section{Kaynaklar}

Alici, N. ve Göker Paktaş, M. (2020). İç mekânda renk algısı ve psikolojik etkileri, İstanbul Gedik Üniversitesi Güzel Sanatlar ve Mimarlık Fakültesi Dergisi (ISSN: 2651-5210 Ulusal Hakemli Dergi), 2020;3(1).

Archdaily. (2011). Rusakov Workers' Club / Konstantin Melnikov. Erişim adresi (22.07.2021): https://www.archdaily.com/155470/ad-classics-rusakov-workers-club-konstantin-melnikov

Architectuul. (2021). Rusakov İş̧i Kulübü. Erişim Adresi http://architectuul.com/architecture/rusakov-workers-club

Arch365bilgi. (2017). Rusakov Workers' Club / Konstantin Melnikov. Erişim adresi (22.07.2021): http://arch365bilgi.blogspot.com/2017/05/rusakov-workers-club-konstantin-melnikov.html

Arkitektual. (2017). Fallingwater Evi (Şelale Evi). Erişim adresi (22.07.2021): https://www.arkitektuel.com/fallingwater-evi-selale-evi/

Arkitektuel. (2017). Rietveld Schröder Evi. Erişim adresi (22.07.2021): https://www.arkitektuel.com/rietveld-schroder-evi/

Atalayer, F. (1994). Temel Sanat Öğeleri, Anadolu Üniversitesi Güzel Sanatlar Fakültesi Yayınları, Eskişehir.

Atalayer, F. (1995). Anadolu Üniversitesi Güzel Sanatlar Fakültesi Yüksek Lisans Ders Notları.

Aydınlı, S. (1993). Mimarlıkta Estetik Değerler, iтÜ Müh. Mim. Fakültesi Yayınları, İstanbul.

Bauhaus-dessau. (n.d.). Bauhaus Building by Walter Gropius (1925-26). Erişim adresi (22.07.2021): https://www.bauhaus-dessau.de/en/architecture/bauhaus-building.htm

Birol, G. (2006). Modern mimarlığın ortaya çıkışı ve gelişimi. Megaron.-Mimarlar Odası Balıkesir Şubesi Yayını, Ekim 2006, s.3-16.

Bingöl, Y. (t.y.). Bauhaus ve Eğitim İlkeleri. Erişim adresi (16.08.2021): http://mobbig.mo.org.tr/wpcontent/uploads/2020/07/MOBBIG-XXIX_Sunus_Yuksel-Bingol.pdf

Birol, G. (1996). 19. Yüzyıl Endüstri Devrimi Sonrası Mimari Akımlar (Yayınlanmamış Yüksek Lisans Tezi), Balıkesir Üniversitesi Fen Bilimleri Enstitüsü.

Bulat, S., Bulut, M. ve Aydın, B. (2014). Bauhause Tasarım Okulu, Atatürk Üniversitesi Sosyal Bilimler Enstitüsü Dergisi, 18 (1):105-120.

Ching D. K. F. (2007). Mimarlık Biçim, Mekân ve Düzen, Yem Yayınları, i̇stanbul.

Dalay, L. (2020). Bauhaus İlkeleri ile Tasarım. Erişim adresi (17.08.2021): http://www.egelife.com/bauhaus-i-lkeleri-ile-tasarim

Enstice, W. ve Peters, M. (1990). Drawing Space, Form, Expression, Englewood Cliffs, New Jersey.

Erkol, i. (2009). Utarit İzgi ve Türkiye'de Modern Mimarlık (Yayınlanmamış Yüksek Lisans Tezi), İstanbul Teknik Üniversitesi, Fen Bilimleri Enstitüsü.

Göktan, M. Ç. (2015). Fütürizm sanat akımının oluşumunda fotoğrafın önemi, DOI: 10.7816, Ulakbilge, Cilt:3, Sayı:5, Volume:3, Issue:5.

Hasol, D. (2002). Ansiklopedik Mimarlık Sözlüğü, 8. Baskı, Yem Yayınları, İstanbul. 
James-Chakraborty, K. (2019). Bauhaus Kültürü (Çev: Elçin Gen). Erişim adresi (05.01.2020): https://www.e-skop.com/skopdergi/bauhaus-kulturu/4580

Kaptan, B. (1997). İç Mimaride Form Mekân Illişkisi (Yüksek Lisans Tezi), Anadolu Üniversitesi, Eskişehir.

Kavrakoğlu, F. (2014). Çağdaş Sanata Varış 69 - Le Corbusier 1918 Pürizm. Erişim adresi (22.07.2021): https://kavrakoglu.com/cagdas-sanata-varis-69-le-corbusier-1918-purizm/

Keçeci, K. (2020). Notre Dame du Haut Ronchamp -Modernist Başyapıt. Erişim adresi (22.07.2021): https://dokmimarlik.com/notre-dame-du-haut-ronchamp-modernist-basyapit/

Loos, A. (2014). Mimarlık Üzerine (Çev: Alp Tümertekin, Nihat Ülner) Janus Yayıncılık.

Mays, J. B. (2006). Modernist Mimarinin Öncüleri: Weissenhofsiedlung Mahallesi. Erişim adresi (21.01.2020): http://www.yapi.com.tr/haberler/modernist-mimarinin-onculeriweissenhofsiedlung-mahallesi_49427.html

Öztürk, D. (2010). Mimarlık Savaşa Hizmet Edince. Erişim adresi (19.08.2020): https://v3.arkitera.com/h54060-mimarlik-savasa-hizmet-edince.html

Özyalvaç, A. (2013). Mimarlıkta modernite kavramı ve Türkiye. FSM ilımi Araştırmalar Insan ve Toplum Bilimleri Dergisi, 0 (1), 294-306. Erişim adresi (19.08.2021): https://dergipark.org.tr/en/pub/fsmia/issue/6473/85528

Roth, L. M. (2000). Mimarlığın Öyküsü Öğeleri, Tarihi ve Anlamı, Kabalcı Yayınevi, İstanbul.

Sunal, B. (2016). Pürizm Nedir. Erişim adresi (12.01.2020): https://www.makaleler.com/purizm-nedir

Süzen, H. N. (2018). 20. Yüzyıl Sanat Akımları Nedenleri Niçinleri ve Etkileri, Erişim adresi (15.08.2021):

https://www.researchgate.net/publication/329802526_20_YUZYIL_SANAT_AKIMLARI_NEDENL ERI_NICINLERI_VE_ETKILERI_1

Tasarım Akademi. (2018). Bauhaus Sanat Akımı. Erişim adresi (05.01.2020): https://www.tasarimakademi.org/bauhaus-sanat-akimi.html

Thurell, S. (1989). The Shadow Of a Thought, The Janus Consept In Architecture, Stockholm.

Yaman, İ. Ş., Ekim, T., Sungur, S. ve Özer, C. (2012). Çağdaş Dünya Sanatı, Devlet Kitapları, 1. Baskı.

Yıldırım, Ö. (2018). Konstrüktivizm (Yapıcılık) Nedir. Erişim adresi (04.01.2020): http://www.sanatsal.gen.tr/konstruktivizm-yapicilik-nedir-ne-demektir/

Zelanzky, P. ve Fisher, M. P. (1987). Shaping Space, Holt, Rinehart and Winston Inc., New York (USA.

Xoxo Digital. (2018). Bauhaus Mimarisi Üzerine. Erişim adresi (10.02.2020): https://xoxodigital.com/post/11679/bauhaus-mimarisi-uzerine

Wong, W. (1972). Principles of Dimensional Design. Erişim adresi (22.01.2020): https://books.google.com.tr/books?hl=tr\&lr=\&id=4ctaiL6Cd4YC\&oi=fnd\&pg=PA15\&dq=w+wo ng+principles+two+dimensional+design+pdf\&ots=CYjTQQYAt_\&sig=8ht1dLlzpF79dO10IgEs2r8f TH8\&redir_esc=y\#v=onepage \&q\&f=false

World Monuments Found. (2016). Rusakov Club. Erişim adresi (22.07.2021): https://www.wmf.org/project/rusakov-club 